\title{
Direct and Indirect Cost of Obesity: A Systematic Review
}

\author{
Galih Putri Wulandari ${ }^{1} \&$ Susi Ari Kristina ${ }^{2}$ \\ ${ }^{1}$ Undergraduate Program, Faculty of Pharmacy, Universitas Gadjah Mada, Yogyakarta, Indonesia \\ ${ }^{2}$ Department of Pharmaceutics, Faculty of Pharmacy, Universitas Gadjah Mada, Yogyakarta, Indonesia \\ Correspondence: Susi Ari Kristina, Department of Pharmaceutics, Faculty of Pharmacy, Universitas Gadjah Mada, \\ Yogyakarta, Indonesia. E-mail: susiari_k@ugm.ac.id
}

Received: July 20, 2018 Accepted: August 17, 2018 Online Published: August 28, 2018

doi:10.5539/gjhs.v10n9p122 URL: https://doi.org/10.5539/gjhs.v10n9p122

\begin{abstract}
Obesity is a predictor for various diseases, especially for non-communicable diseases. Obesity impacts large economic burden for patient, healthcare system and the government. This study aims to review the economic impact of obesity worldwide, in terms of direct and indirect costs component of obesity. A systematic review was performed on PubMed, Science Direct and Google Scholar databases during the period 2008-2018. A combination key terms such as "obesity", "overweight and obesity", "weight excess", "economic burden", "financial burden", "cost", "cost of illness", "direct cost", "healthcare cost", "indirect cost", "productivity loss cost", and "adult" were used for the search. Relevant original articles published in English and reported both direct and indirect cost of obesity were included in the study. A total of 61 studies were retrieved, then 8 studies were finally selected that met all eligibility criteria which reported both direct and indirect cost of obesity in developing and developed countries. Almost all of studies reported that indirect costs have more proportion than direct costs. The economic burden of obesity was estimated to $0.13-0.22 \%$ of Gross Domestic Product (GDP) and 1.5-5.6\% of health expenditures. Our review indicated that the direct and indirect cost of obesity has a significant impact to healthcare system and the country. Some health programs and policies are required and should be implemented as soon as possible to reduce the economic impact of obesity.
\end{abstract}

Keywords: obesity, direct cost, indirect cost, economic burden

\section{Introduction}

Obesity is a risk factor leading to many chronic diseases such as cardiovascular diseases, diabetes type 2, and various types of cancer (Pi-Sunyer, 2009). To date, obesity is not only a health problem increasing in developed countries, but also in developing countries (Bhurosy \& Jeewon, 2014). The WHO report (World Health Organization, 2017) stated that by 2016, exceed than 1.9 billion (39\%) of adults are overweight and more than 650 million (13\%) are obese. World Obesity Federation (World Obesity Federation, 2015) projected that by 2015, there are 2.7 billion general population worldwide will be obese.

Obesity will continues increase as a result of globalization. Globalization impacts in lifestyle changes that lead to energy imbalance between calories consumed with calories spent (Costa-Font \& Mas, 2016). If obesity continues to rise, obesity will has a significant impact on healthcare costs in the future (Erixon, 2017). Therefore, the increased incidence of obesity will exacerbate the disease burden and economic burden (Rtveladze et al., 2013).

Research on the economic impact due to obesity has been conducted in some countries both in developed and developing countries. For example, Canada, Germany, Thailand, and Nigeria. The economic burden commonly referred to as the cost of illness which defined as direct and indirect costs (Sakdapolrak, Seyler, \& Ergler, 2013). Cost of illness used to describe healthcare spending in general. Direct costs comprise all direct medical and non-medical costs for diagnosis, treatment, and transportation. Indirect costs are the costs of productivity loss due to sickness and premature death (Jo, 2014). Latest data from World Obesity Federation (World Obesity Federation, 2015 ) estimated that the global medical cost to treat obesity-related diseases reach $\$ 1.2$ trillion per year by 2025 . Therefore, the existence of effort to tackle obesity is a important thing.

Previously there has been a systematic review of obesity. However, most of the existing ones only reveal the economic burden in terms of direct costs (Thompson \& Wolf, 2001). In addition, there is also a systematic review 
that discusses the costs of both direct and indirect costs with the data collection of the 1990s or just one region only (Withrow \& Alter, 2011). This study aims to show the latest direct and indirect cost of obesity that provide new evidence to make obesity control.

\section{Methods}

A systematic review was conducted to assess direct and indirect cost of obesity. There were 3 main steps to formulate the result studies; first we identify and select related research about our topic. Second, we assess the retrieved research that met all eligibility criteria. We made the review and data extraction for each study at the final step.

\subsection{Study Identification}

PubMed, Science Direct and Google Scholar were initially searched in April, 2018. A literature search for published articles were limited in English language to select studies that calculating direct and indirect cost of obesity in a study population. The period of time for the analysis was 2008 to 2018 . Key terms used were as follows: "obesity" OR "overweight and obesity" OR "weight excess" AND "economic burden" OR "financial burden" OR "cost" OR "cost of illness" AND "direct cost" OR "healthcare cost" AND "indirect cost" OR "productivity loss cost" AND "adult". Inclusion and exclusion criteria were shown in Table 1.

Table 1. Inclusion and exclusion criteria for the retrieved articles

\begin{tabular}{|c|c|}
\hline Inclusion Criteria & Exclusion Criteria \\
\hline 1. Published in the English language & 1. Review articles, letters and comments \\
\hline 2. Time frame year from $2008-2018$ & 2. Exclusively related to the groups of people such as \\
\hline 3. Reportcost of obesity & workplace or rural regions \\
\hline 4. Available in full-text & 3. Not mention both direct and indirect cost of obesity \\
\hline
\end{tabular}

\subsection{Study Retrieved Process}

A total of 61 studies were initially retrieved. After further tracking references from the retrieved studies, only 8 studies were finally selected that met all eligibility criteria. The other 53 studies were excluded due to the full-text cannot be accessed, not mentioning both direct and indirect cost or unclear cost items and duplicate topic of the articles. The PRISMA diagram of retrieved studies was shown in Figure 1. 


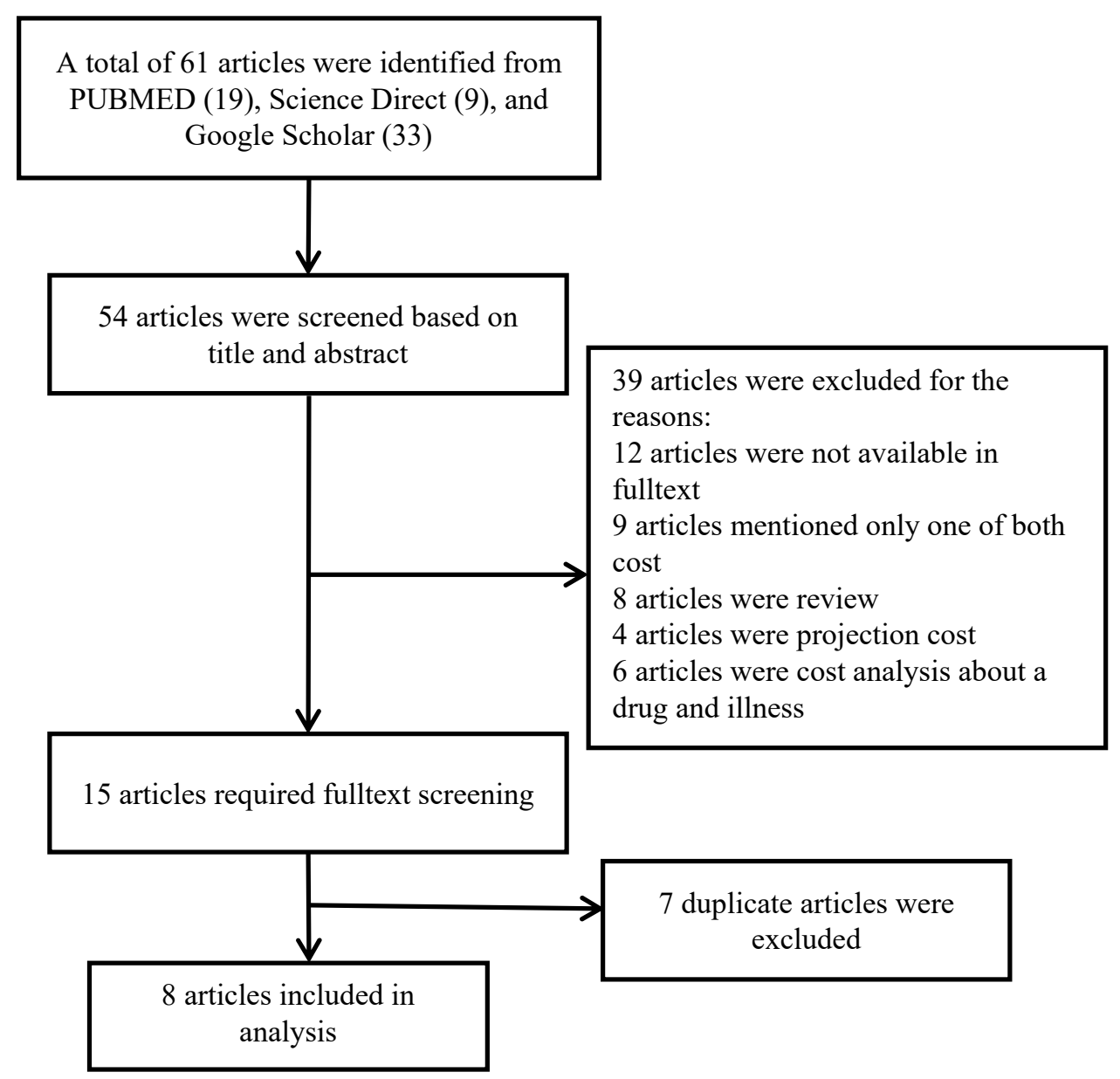

Figure 1. PRISMA diagram of retrieved studies.

\subsection{Data Extraction}

Data were independently extracted by 2 researchers. Data extraction form contained the information on the methodology, the description of cost components of each study, and obesity related diseases as a focus of study. Non-agreement on the extracted data was resolved by discussion among the authors.

\subsection{Study Quality Assessment}

The study quality is done by two authors using a subjective 10-point quality scale in addition to the 100-point Quality of Health Economic Studies (QHES) questionnaire.

\section{Results}

\subsection{Literature Search}

A total of 61 articles were retrieved from the combined searches from PubMed, Science Direct and Google Scholar. Title and abstract of the 61 identified articles were independently assessed by the two authors. Based on title and abstract, 7 articles were ineligible to be reviewed. The abstract of the remaining studies, 39 articles were excluded for many reasons such as articles were not available in fulltext, only mentioned either direct or indirect cost, a review articles, letters and comments, also projected cost of obesity. Futhermore, there were 7 duplicated articles so finally 8 articles were included in the review. The included studies were conducted in 5 countries. Three studies were conducted in Germany (Effertz, Engel, Verheyen, \& Linder, 2016; Konnopka, Bödemann, \& König, 2011; Lehnert, Streltchenia, Konnopka, Riedel-Heller, \& König, 2015), two studies were conducted in Canada (Dee et al., 2015; Moffatt et al., 2011), and the remaining studies were conducted in Korea (Kang, Jeong, Cho, Song, \& Kim, 2011), New Zealand (Lal, Moodie, Ashton, Siahpush, \& Swinburn, 2012) and Thailand (Pitayatienanan et al., 2014). 


\subsection{Study Perspective}

Most of studies used societal perspective to measure economic burden of obesity both direct cost and indirect cost. Only one study used third-party payer that was in Germany (Effertz et al., 2016). Cost included in cost of illness from societal perspective are medical cost, morbidity cost, mortality cost and transportation or non-medical costs while The German public health insurance system assessed health, unemployment cost, retirement, accidents and nursing care.

\subsection{Study Methodology}

Approaches of cost of illness studies in terms cost of obesity were varied. There were prevalence and incidence-based, top-down and bottom-up, human-capital and friction cost approach to calculate direct cost and indirect. From the included studies, there were 4 studies using prevalence-based (Kang et al., 2011; Lal et al., 2012; Moffatt et al., 2011; Pitayatienanan et al., 2014), 1 study using incidence-based (Moffatt et al., 2011), 3 studies using top-down approach (Dee et al., 2015; Konnopka et al., 2011; Lal et al., 2012), 3 studies using bottom-up approach (Dee et al., 2015; Effertz et al., 2016; Lal et al., 2012), 4 studies using human capital approach (Konnopka et al., 2011; Lehnert et al., 2015; Moffatt et al., 2011; Pitayatienanan et al., 2014) and 1 study using friction cost approach (Lehnert et al., 2015).

The prevelence and incidence-based approach were classified based on the prespective in which the epidemiological data used. Prevalence-based approach estimated the sum of total cases of death and hospitalization attributable to disease in a given year period and then estimate the costs that derived from those deaths or hospitalization while incidence-based approach estimated the sum of new cases of death or hospitalization in a year timeframe and apply a lifetime cost to these new cases estimated (Jo, 2014).

The top-down or population-based known as the epidemiological or attributable risk method. This approach using aggregated data along with a risk-attributable fraction (RAF). While, bottom-up approach can be stratified into two steps. The first step was to measure and quantify the input parameters employed and the second step was to estimate the unit costs of the inputs used to generate and confer specific medical and health care services. The total costs derived from the multiplication of unit costs by the quantities used (Jo, 2014).

The last approaches in cost of illness studies were human capital and friction approach. Human capital approach was proposed to estimate the value of the present value of his or her future earnings under the assumption that we used future earnings as a proxy for future productivity, although in many cases the future earnings did not accurately reflect future productivity. While, the friction cost approach estimated the value of loss of productivity from the unemployment replaced the present value of a worker's future earnings until the sick person return or was finally replaced.

We included 8 studies in this review with detailed characteristics of these studies are presented in Table 2. 
Table 2. Characteristics of the included studies

\begin{tabular}{|c|c|c|c|c|c|c|c|c|c|c|}
\hline Author, Year & Country & Perspective & $\begin{array}{l}\text { Time } \\
\text { Frame }\end{array}$ & Sample & Method & $\begin{array}{l}\text { DR } \\
(\%)\end{array}$ & Direct Cost & $\begin{array}{l}\text { Indirect } \\
\text { Cost }\end{array}$ & $\begin{array}{l}\% \\
\text { GDP }\end{array}$ & $\begin{array}{l}\% \\
\mathrm{HE}\end{array}$ \\
\hline $\begin{array}{l}\text { Dee, } 2015 \text { (Dee et al., } \\
\text { 2015) }\end{array}$ & $\begin{array}{l}\text { Ireland, } \\
\text { Canada }\end{array}$ & Societal & 2009 & $\begin{array}{l}\text { Ireland } \\
\text { population }\end{array}$ & $\begin{array}{l}\text { Top-down \& } \\
\text { bottom-up } \\
\text { approach }\end{array}$ & 4 & $\begin{array}{l}\text { US\$ } 646 \\
\text { million }\end{array}$ & $\begin{array}{l}\text { US\$ } 1,373 \\
\text { million }\end{array}$ & NM & NM \\
\hline $\begin{array}{l}\text { Effertz, } 2016 \text { (Effertz et } \\
\text { al., 2016) }\end{array}$ & Germany & $\begin{array}{l}\text { Third-party } \\
\text { payer }\end{array}$ & $\begin{array}{l}2008 \text { to } \\
\text { mid-2012 }\end{array}$ & $\begin{array}{l}\text { Insured } \\
\text { population }\end{array}$ & $\begin{array}{l}\text { Bottom-up } \\
\text { approach }\end{array}$ & 2 & $\begin{array}{l}\text { US\$ } 33,647 \\
\text { million }\end{array}$ & $\begin{array}{l}\text { US\$ } 38,524 \\
\text { million }\end{array}$ & $\mathrm{NM}$ & NM \\
\hline $\begin{array}{l}\text { Kang, } 2011 \text { (Kang et } \\
\text { al., 2011) }\end{array}$ & Korea & Societal & 2005 & $\begin{array}{l}\text { Adult } \geq \\
\text { 20years }\end{array}$ & Prevalence-based & 6 & $\begin{array}{l}\text { US\$ } 1,081 \\
\text { million }\end{array}$ & $\begin{array}{l}\text { US\$ } 706 \\
\text { million }\end{array}$ & 0.22 & 3.7 \\
\hline $\begin{array}{l}\text { Konnopka, } 2011 \\
\text { (Konnopka et al., 2011) }\end{array}$ & Germany & Societal & 2002 & $\begin{array}{l}15-90 \\
\text { years old }\end{array}$ & $\begin{array}{l}\text { Top-down } \\
\text { approach; Human } \\
\text { capital approach }\end{array}$ & $\begin{array}{l}0 ; \\
3 ; \\
10\end{array}$ & $\begin{array}{l}\text { US\$ } 5,557 \\
\text { million }\end{array}$ & $\begin{array}{l}\text { US\$ 5,746 } \\
\text { million }\end{array}$ & $\mathrm{NM}$ & 2.1 \\
\hline $\begin{array}{l}\text { Lal, } 2012 \text { (Lal et al., } \\
\text { 2012) }\end{array}$ & $\begin{array}{l}\text { New } \\
\text { Zealand }\end{array}$ & Societal & 2006 & $\begin{array}{l}\text { New } \\
\text { Zealand } \\
\text { population }\end{array}$ & $\begin{array}{l}\text { Prevalence-based; } \\
\text { bottom-up } \\
\text { approach; } \\
\text { top-down } \\
\text { approach }\end{array}$ & NM & $\begin{array}{l}\text { US\$ } 414 \\
\text { million }\end{array}$ & $\begin{array}{l}\text { US\$ } 65 \\
\text { million } \\
(\text { FCA); } \\
\text { US\$ } 149 \\
\text { million } \\
(\text { HCA }) \text { ) }\end{array}$ & $\mathrm{NM}$ & 4.4 \\
\hline $\begin{array}{l}\text { Lehnert, } 2015 \text { (Lehnert } \\
\text { et al., 2015) }\end{array}$ & Germany & Societal & 2008 & $\begin{array}{l}18-74 \\
\text { years old }\end{array}$ & $\begin{array}{l}\text { Human capital } \\
\text { approach; Friction } \\
\text { cost approach }\end{array}$ & 5 & $\begin{array}{l}\text { US\$ 9,899 } \\
\text { million }\end{array}$ & $\begin{array}{l}\text { US\$ 9,330 } \\
\text { million }\end{array}$ & NM & 3.27 \\
\hline $\begin{array}{l}\text { Moffat, } 2011 \text { (Moffatt } \\
\text { et al., 2011) }\end{array}$ & $\begin{array}{l}\text { Alberta, } \\
\text { Canada }\end{array}$ & Societal & 2005 & $\begin{array}{l}\text { Alberta } \\
\text { population }\end{array}$ & $\begin{array}{l}\text { Prevalence-based; } \\
\text { Incidence-based; } \\
\text { Human capital } \\
\text { approach }\end{array}$ & NM & $\begin{array}{l}\text { US\$ } 481 \\
\text { million }\end{array}$ & $\begin{array}{l}\text { US\$ } 492 \\
\text { million }\end{array}$ & $\mathrm{NM}$ & 5.6 \\
\hline $\begin{array}{l}\text { Pitayatienanan, } 2014 \\
\text { (Pitayatienanan et al., } \\
\text { 2014) }\end{array}$ & Thailand & Societal & 2009 & $\begin{array}{l}\text { Adult Thai } \\
\text { population }\end{array}$ & $\begin{array}{l}\text { Prevalence-based; } \\
\text { Human capital } \\
\text { approach }\end{array}$ & 3 & $\begin{array}{l}\text { US\$ } 168 \\
\text { million }\end{array}$ & $\begin{array}{l}\text { US\$ } 395 \\
\text { million }\end{array}$ & 0.13 & 1.5 \\
\hline
\end{tabular}

* DR: Discounting Rate;

FCA: Friction Cost Approach;

HCA: Human Capital Approach;

NM: Not Mentioned;

GDP: Gross Domestic Product;

HE: Health Expenditure.

\subsection{Direct and Indirect Cost Components}

After reviewed done, there were some substantial heterogeneity in the direct and indirect cost of obesity. First, there was variation items used to determine both direct and indirect cost showed in Table 3. The most dominated item of direct cost was healthcare cost, meanwhile for the indirect cost was premature mortality cost. 
Table 3. Direct and indirect cost items of obesity in included studies

\begin{tabular}{|c|c|c|}
\hline Author, Year & Direct cost item & Indirect cost item \\
\hline $\begin{array}{l}\text { Dee, } 2015 \text { (Dee et } \\
\text { al., 2015) }\end{array}$ & $\begin{array}{l}\text { Healthcare cost (Healthcare utilisation and } \\
\text { drug cost) }\end{array}$ & Work abseenteeism and premature mortality \\
\hline $\begin{array}{l}\text { Effertz, } 2016 \\
\text { (Effertz et al., 2016) }\end{array}$ & $\begin{array}{l}\text { Health services and products, medical } \\
\text { treatment of nursing care, rehabilitation } \\
\text { treatment and resources, accident, pain and } \\
\text { suffering from comorbidities }\end{array}$ & $\begin{array}{l}\text { Sick leave, rehabilitation compensation, early } \\
\text { retirement pensions, pensions for widows and } \\
\text { orphan, unemployment compensation and welfare, } \\
\text { mortality }\end{array}$ \\
\hline $\begin{array}{l}\text { Kang, } 2011 \text { (Kang } \\
\text { et al., 2011) }\end{array}$ & $\begin{array}{l}\text { Inpatient care, outpatient care, medication } \\
\text { and pharmaceuticals }\end{array}$ & $\begin{array}{l}\text { loss of productivity due to hospitalization, time costs, } \\
\text { transportation cost, nursing fees }\end{array}$ \\
\hline $\begin{array}{l}\text { Konnopka, } 2011 \\
\text { (Konnopka et al., } \\
\text { 2011) }\end{array}$ & $\begin{array}{l}\text { Inpatient and outpatient treatment, } \\
\text { rehabilitation, health protection, ambulance, } \\
\text { administration, research, education, } \\
\text { investments and other facilities }\end{array}$ & Sickness absence, early retirement and mortality \\
\hline $\begin{array}{l}\text { Lal, 2012 (Lal et al., } \\
\text { 2012) }\end{array}$ & $\begin{array}{l}\text { Hospital costs (inpatient and outpatient), allied } \\
\text { health professionals costs, general practitioner } \\
\text { visits, residential/aged care, pharmaceuticals } \\
\text { and laboratory tests }\end{array}$ & $\begin{array}{l}\text { Permanent absences due to premature death, training } \\
\text { and recruitment costs, short-term absenteeism due to } \\
\text { illness }\end{array}$ \\
\hline $\begin{array}{l}\text { Lehnert, } 2015 \\
\text { (Lehnert et al., } \\
\text { 2015) }\end{array}$ & $\begin{array}{l}\text { Inpatient and outpatient treatment, } \\
\text { rehabilitation, as well as for health protection, } \\
\text { ambulance, administration, research and } \\
\text { education, investments, and other facilities }\end{array}$ & $\begin{array}{l}\text { loss of productivity from paid and unpaid work due to } \\
\text { sickness absence, early retirement, and mortality }\end{array}$ \\
\hline $\begin{array}{l}\text { Moffat, } 2011 \\
\text { (Moffatt et al., } \\
\text { 2011) }\end{array}$ & $\begin{array}{l}\text { Hospital care, drugs, physician care, } \\
\text { instutional care, additional cost }\end{array}$ & Short and long-term disability, premature mortality \\
\hline $\begin{array}{l}\text { Pitayatienanan, } \\
2014 \\
\text { (Pitayatienanan et } \\
\text { al., 2014) }\end{array}$ & $\begin{array}{l}\text { Healthcare cost (Inpatient and outpatient } \\
\text { services) }\end{array}$ & $\begin{array}{l}\text { Productivity loss due to premature } \\
\text { mortality, hospital-related absenteeism }\end{array}$ \\
\hline
\end{tabular}

\subsection{The value of direct cost}

The direct cost of study conducted in Ireland was US\$ 646 million for Republic of Ireland and North Ireland (Dee et al., 2015). There were three studies conducted in Germany with annual direct costs was approximately US\$ 33,647 million (Effertz et al., 2016), US\$ 5,557 million corresponding to $2.1 \%$ of the overall German health expenditures in 2002 (Konnopka et al., 2011) and US\$ 9,899 million corresponding to $3.27 \%$ of total German health care expenditures in 2008 (Lehnert et al., 2015). Meanwhile, direct cost of obesity in Korea was estimated approximately US\$ 1,081 million (men: US\$ 497 million, women: US\$ 584 million) (Kang et al., 2011). Study in New Zealand showed that health care costs attributable to overweight and obesity were estimated to be US\$ 414 million or 4.4\% of New Zealand's total health care expenditure in 2006 (Lal et al., 2012). In Alberta from Moffat study showed that the direct cost of excess weight was US\$ 481 million (Moffatt et al., 2011). The last study conducted in Thailand showed that the health care cost attributable to obesity was estimated at US\$168 million or $1.5 \%$ of national health expenditure (Pitayatienanan et al., 2014).

\subsection{The value of indirect cost}

Dee study reported that productivity loss due to obesity was up to US\$ 1,373 million for Republic of Ireland and North Ireland (Dee et al., 2015). Next, there were the indirect cost of study conducted in Germany was US\$ 38,524 million (Effertz et al., 2016), US\$ 5,746 million (Konnopka et al., 2011), and US\$ 9,330 million(Lehnert et al., 2015). Meanwhile, indirect cost of obesity in Korea was estimated at approximately US\$ 706 million (men: US\$ 527 million, women: US\$ 178 million). The study in New Zealand showed that the costs of lost productivity using the FCA were estimated to be US\$ 65 million and US\$ 149 million using the HCA (Lal et al., 2012). Indirect cost in Alberta was amount up to US\$ 492 million (Moffatt et al., 2011). Lastly, study in Thailand mentioned cost 
of productivity loss, the cost of hospital-related absenteeism and the cost of premature mortality attributable to obesity was estimated at US\$395 million whereas the cost of productivity loss accounting for $54 \%$ of the total cost of obesity (Pitayatienanan et al., 2014).

\subsection{The heterogeneity of included studies}

First, in the included studies, they mentioned the cost of obesity using their country currency. Four studies using Euro unit (Dee et al., 2015; Effertz et al., 2016; Konnopka et al., 2011; Lehnert et al., 2015), three studies using Dollar unit both American dollars(Kang et al., 2011), Canada(Moffatt et al., 2011) and New Zealand(Lal et al., 2012) and the other study using Baht unit(Pitayatienanan et al., 2014). Here, the researcher converted to United States Dollar in year 2018 to gain the clear value of cost.

The next heterogeneity was also shown for the discounting rate. The different discounting rate used in the included studies. There were studies using 0\% (Konnopka et al., 2011), 2\% (Effertz et al., 2016), 3\% (Konnopka et al., 2011), 4\% (Dee et al., 2015), 5\% (Lehnert et al., 2015), 6\% (Kang et al., 2011) and 10\% (Konnopka et al., 2011). Also there were studies did not mention about the discounted rate (Lal et al., 2012; Moffatt et al., 2011).

\subsection{Obesity-related diseases}

Various obesity-related diseases mentioned in the included studies. Futher gathered information about it listed in Table 4. Diabetes mellitus included in all of 8 studies. Additionally, colon cancer, hypertension and coronary heart disease were the disease included in almost all studies except one study. Therefore, diabetes mellitus, hypertension, colon cancer and coronary heart disease were the most commonly considered co-morbidities of obesity.

Table 4. Obesity-related disease in each studies

\begin{tabular}{|c|c|c|c|c|c|c|c|c|}
\hline 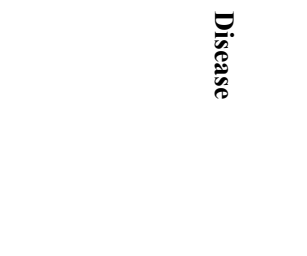 & 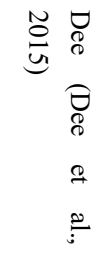 & 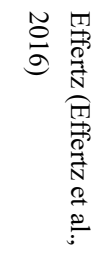 & 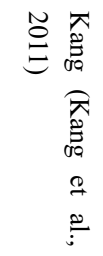 & 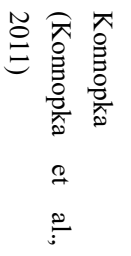 & 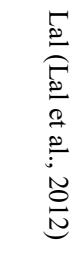 & 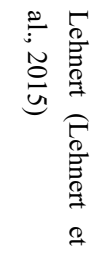 & 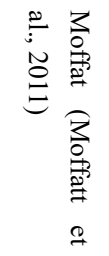 & 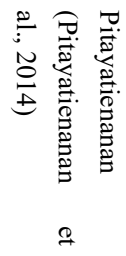 \\
\hline \multicolumn{9}{|l|}{ Cancer disease } \\
\hline Colon & $\sqrt{ }$ & $\sqrt{ }$ & $\sqrt{ }$ & $\sqrt{ }$ & $\sqrt{ }$ & $\sqrt{ }$ & & $\sqrt{ }$ \\
\hline Oesophagus & $\sqrt{ }$ & & & $\sqrt{ }$ & & $\sqrt{ }$ & & \\
\hline Gallbladder & $\sqrt{ }$ & & & $\sqrt{ }$ & & $\sqrt{ }$ & & \\
\hline Pancreas & $\sqrt{ }$ & & & $\sqrt{ }$ & & $\sqrt{ }$ & & \\
\hline Breast & $\sqrt{ }$ & & & $\sqrt{ }$ & $\sqrt{ }$ & $\sqrt{ }$ & & $\sqrt{ }$ \\
\hline Kidney & $\sqrt{ }$ & & & $\sqrt{ }$ & $\sqrt{ }$ & $\sqrt{ }$ & & \\
\hline Endometrium & $\sqrt{ }$ & & & $\sqrt{ }$ & $\sqrt{ }$ & $\sqrt{ }$ & & $\sqrt{ }$ \\
\hline Prostate & & & & $\sqrt{ }$ & & $\sqrt{ }$ & & \\
\hline Stomach & & & & $\sqrt{ }$ & & $\sqrt{ }$ & & \\
\hline Liver & & & & $\sqrt{ }$ & & $\sqrt{ }$ & & \\
\hline Non-Hodkin's lymphoma & & & & $\sqrt{ }$ & & $\sqrt{ }$ & & \\
\hline Multiple myeloma & & & & $\sqrt{ }$ & & $\sqrt{ }$ & & \\
\hline Leukimia & & & & $\sqrt{ }$ & & $\sqrt{ }$ & & \\
\hline \multicolumn{9}{|l|}{ Endocrinological disease } \\
\hline Diabetes mellitus & $\sqrt{ }$ & $\sqrt{ }$ & $\sqrt{ }$ & $\sqrt{ }$ & $\sqrt{ }$ & $\sqrt{ }$ & $\sqrt{ }$ & $\sqrt{ }$ \\
\hline Hyperlipidemia & & & $\sqrt{ }$ & $\sqrt{ }$ & & $\sqrt{ }$ & & $\sqrt{ }$ \\
\hline \multicolumn{9}{|l|}{ Cardiovascular disease } \\
\hline Hypertension & $\sqrt{ }$ & & $\sqrt{ }$ & $\sqrt{ }$ & $\sqrt{ }$ & $\sqrt{ }$ & $\sqrt{ }$ & $\sqrt{ }$ \\
\hline
\end{tabular}




\begin{tabular}{llllllll}
\hline Coronary heart disease & $\sqrt{ }$ & $\sqrt{ }$ & $\sqrt{ }$ & $\sqrt{ }$ & $\sqrt{ }$ & $\sqrt{ }$ & $\sqrt{ }$ \\
Stroke & $\sqrt{ }$ & $\sqrt{ }$ & & $\sqrt{ }$ & & & $\sqrt{ }$ \\
\hline
\end{tabular}

Digestive disease

Gallbladder disease

$\sqrt{ } \quad \sqrt{ }$

$\sqrt{ }$

$\sqrt{ }$

\begin{tabular}{|c|c|c|c|c|c|c|}
\hline Others & & & & & & \\
\hline Pulmonary embolism & $\sqrt{ }$ & & & & & $\sqrt{ }$ \\
\hline Low back pain & $\sqrt{ }$ & & & & & \\
\hline Asthma & $\sqrt{ }$ & $\sqrt{ }$ & & & $\sqrt{ }$ & \\
\hline Osteoarthritis & & $\sqrt{ }$ & $\sqrt{ }$ & $\sqrt{ }$ & $\sqrt{ }$ & $\sqrt{ }$ \\
\hline Arteriosclerosis & & $\sqrt{ }$ & & & & \\
\hline Dementia & & $\sqrt{ }$ & & & & \\
\hline Sleep apnea & & $\sqrt{ }$ & & & & \\
\hline Steatohepatitis & & $\sqrt{ }$ & & & & \\
\hline Glomerulosclerosis & & $\sqrt{ }$ & & & & \\
\hline Musculoskeletal defects & & $\sqrt{ }$ & & & & \\
\hline Early onset on puberty & & $\sqrt{ }$ & & & & \\
\hline Depression & & & & & $\sqrt{ }$ & $\sqrt{ }$ \\
\hline
\end{tabular}

\section{Discussion}

Obesity is a serious health problem in $21^{\text {st }}$ century (Afzal, 2017) which always increasing around the world both developed and developing country (Abelson \& Kennedy, 2004). The basic cause of obesity is an energy imbalance between calories consumed and calories expended. It happens if someone often consuming unhealthy diets and less physical activity and those drive the rising of non communicable disease (NCD) including heart disease, stroke, cancer, diabetes and chronic lung disease, are collectively responsible for almost $70 \%$ of all deaths worldwide (World Health Organization, 2017). Besides that, economic burden of obesity predicted reach 1.2 trillion in 2025 (World Obesity Federation, 2015).

Cost of obesity including direct cost and indirect cost. In schizoprenia case, indirect cost up to three till four times of direct cost (Tajima-Pozo, de Castro Oller, Lewczuk, \& Montañes-Rada, 2015). In this review, 5 studies showed indirect cost of obesity also greater than direct cost up to twice. The major item effect to indirect cost is cost of premature mortality. Obesity is a condition that plays a role in premature mortality incidence (Council \& Population, 2015). Burden of premature mortality incidence can be calculated by YLL (years of life lost due to premature death) (World Health Organization, 2018a) and YLL is known contribute approximately $70 \%$ of DALY calculation (Murthy, Nandakumar, Pruthvish, George, \& Mathew, 2010). Fontaine study (2003) (Fontaine, Redden, Wang, Westfall, \& Allison, 2003) conclude that obesity linked to premature mortality. Obesity known has big impact to life span and younger age is very risky run into this. The Global BMI Mortality Collaboration (2016) (Di Angelantonio E et al., 2016) also stated that obesity associated with incresing risk of premature mortality. The risk of premature mortality before age 70 years is about three times in obese people.

Based on the review, cardiovascular diseases, endocrinological diseases and cancer diseases are the most type obesity-related diseases. All of the obesity-related diseases are non-communicable diseases (NCDs) and chronic incidence, so we have to pay attention with obesity. WHO reported NCD contribute around $70 \%$ of all deaths worldwide and $82 \%$ of them occur in low and middle income countries (World Health Organization, 2018b).

Due to big burden of obesity, we need many efforts to tackle obesity. Public health strategies in societal level with multisector approach known an effective effort for the prevention of obesity and has been advocated in recent years (Chan \& Woo, 2010; World Obesity Federation, 2015). For example, taxing sugar beverage and junk food to reduce people consuming unhealthy diet and creating a pedestrian friendly park and providing sports equipment to increase physical activity (Chan \& Woo, 2010). There is also evidence that positive changes in food habits and physical activity could contribute to preventing the problem of obesity (Aranceta, Moreno, Moya, \& Anadón, 
2009). As the last choice after taking behavioral efforts, seeking medical help is an essential step because it helps to reduce morbidity and mortality rates among obese individuals (Maria \& Evagelia, 2009).

There were several limitations need to be considered in interpreting the findings of this review. The result study may different and vary across regions because it depends on particular disease/s issues of each country, so the health funding and allocation may also different. Research including in this study was limited to several region hoping it gave an overview of obesity related cost for other countriess. We suggest for further research on cost of obesity conduct in the other countries to find out the approriate economic expenditure towards disease priority related to obesity in their country. Thus, the appropriate public health strategies may also reduce the cost of obesity significantly worldwide.

\section{Conclusions}

Our review indicated that the direct and indirect cost of obesity has a significant impact to healthcare system and the country. Some health programs and policies are required and should be implemented as soon as possible to reduce the economic impact of obesity.

\section{Competing Interests Statement}

The authors declare that there are no competing or potential conflicts of interest.

\section{References}

Abelson, P., \& Kennedy, D. (2004). The obesity epidemic. Science, 304(5676), 1413. https://doi.org/10.1126/science.304.5676.1413

Afzal, M. N. (2017). Obesity: A worldwide epidemic. Journal of Pathobiology and Physiology, 1(1), 1.

Aranceta, J., Moreno, B., Moya, M., \& Anadón, A. (2009). Prevention of overweight and obesity from a public health perspective. $\quad$ Nutrition reviews, $67($ suppl_1), $\quad$ S83-S88. https://doi.org/10.1111/j.1753-4887.2009.00166.x

Bhurosy, T., \& Jeewon, R. (2014). Overweight and obesity epidemic in developing countries: a problem with diet, physical activity, or socioeconomic status? The Scientific World Journal, 2014. https://doi.org/10.1155/2014/964236

Chan, R. S., \& Woo, J. (2010). Prevention of overweight and obesity: how effective is the current public health approach. International journal of environmental research and public health, 7(3), 765-783. https://doi.org/10.3390/ijerph7030765

Costa-Font, J., \& Mas, N. (2016). 'Globesity'? The effects of globalization on obesity and caloric intake. Food Policy, 64, 121-132. https://doi.org/10.1016/j.foodpol.2016.10.001

Council, N. R., \& Population, C. o. (2015). Measuring the Risks and Causes of Premature Death. Summary of Workshops: National Academies Press.

Dee, A., Callinan, A., Doherty, E., O'Neill, C., McVeigh, T., Sweeney, M. R., .. Sharp, L. (2015). Overweight and obesity on the island of Ireland: an estimation of costs. BMJ open, 5(3), e006189. https://doi.org/10.1136/bmjopen-2014-006189

Di Angelantonio E, Bhupathiraju S, Wormser D, Gao P, Kaptoge S, \& et al. (2016). Body-mass index and all-cause mortality: individual-participant-data meta-analysis of 239 prospective studies in four continents. Lancet, 388 , 776-786. https://doi.org/10.1016/S0140-6736(16)30175-1

Effertz, T., Engel, S., Verheyen, F., \& Linder, R. (2016). The costs and consequences of obesity in Germany: a new approach from a prevalence and life-cycle perspective. The European Journal of Health Economics, 17(9), 1141-1158. https://doi.org/10.1007/s10198-015-0751-4

Erixon, F. (2017). Europe's obesity challenge: ECIPE Policy Brief.

Fontaine, K. R., Redden, D. T., Wang, C., Westfall, A. O., \& Allison, D. B. (2003). Years of life lost due to obesity. Jama, 289(2), 187-193. https://doi.org/10.1001/jama.289.2.187

Jo, C. (2014). Cost-of-illness studies: concepts, scopes, and methods. Clinical and molecular hepatology, 20(4), 327. https://doi.org/10.3350/cmh.2014.20.4.327

Kang, J. H., Jeong, B. G., Cho, Y. G., Song, H. R., \& Kim, K. A. (2011). Socioeconomic costs of overweight and obesity in Korean adults. Journal of Korean medical science, 26(12), 1533-1540. 
https://doi.org/10.3346/jkms.2011.26.12.1533

Konnopka, A., Bödemann, M., \& König, H.-H. (2011). Health burden and costs of obesity and overweight in Germany. The European Journal of Health Economics, 12(4), 345-352. https://doi.org/10.1007/s10198-010-0242-6

Lal, A., Moodie, M., Ashton, T., Siahpush, M., \& Swinburn, B. (2012). Health care and lost productivity costs of overweight and obesity in New Zealand. Australian and New Zealand journal of public health, 36(6), 550-556. https://doi.org/10.1111/j.1753-6405.2012.00931.x

Lehnert, T., Streltchenia, P., Konnopka, A., Riedel-Heller, S. G., \& König, H.-H. (2015). Health burden and costs of obesity and overweight in Germany: an update. The European Journal of Health Economics, 16(9), 957-967. https://doi.org/10.1007/s10198-014-0645-x

Maria, P., \& Evagelia, S. (2009). Obesity disease. Health Science Journal, 14, 132-138.

Moffatt, E., Shack, L. G., Petz, G. J., Sauvé, J. K., Hayward, K., \& Colman, R. (2011). The cost of obesity and overweight in 2005: a case study of Alberta, Canada. Canadian Journal of Public Health/Revue Canadienne de Sante'e Publique, 144-148.

Murthy, N. S., Nandakumar, B., Pruthvish, S., George, P. S., \& Mathew, A. (2010). Disability adjusted life years for cancer patients in India. Asian Pac J Cancer Prev, 11(3), 633-640.

Pi-Sunyer, X. (2009). The medical risks of obesity. Postgraduate medicine, 121(6), 21-33. https://doi.org/10.3810/pgm.2009.11.2074

Pitayatienanan, P., Butchon, R., Yothasamut, J., Aekplakorn, W., Teerawattananon, Y., Suksomboon, N., \& Thavorncharoensap, M. (2014). Economic costs of obesity in Thailand: a retrospective cost-of-illness study. BMC health services research, 14(1), 146. https://doi.org/10.1186/1472-6963-14-146

Rtveladze, K., Marsh, T., Webber, L., Kilpi, F., Levy, D., Conde, W., . . Brown, M. (2013). Health and economic burden of obesity in Brazil. PloS one, 8(7), e68785. https://doi.org/10.1371/journal.pone.0068785

Sakdapolrak, P., Seyler, T., \& Ergler, C. (2013). Burden of direct and indirect costs of illness: Empirical findings from slum settlements in Chennai, South India. Progress in Development Studies, 13(2), 135-151. https://doi.org/10.1177/1464993412466506

Tajima-Pozo, K., de Castro Oller, M. J., Lewczuk, A., \& Monta-es-Rada, F. (2015). Understanding the direct and indirect costs of patients with schizophrenia. F1000 Research, 4, 182. https://doi.org/10.12688/f1000research.6699.2

Thompson D, \& Wolf AM. (2001). The medical-care cost burden of obesity. Obes Rev, 2(3), 189-197. https://doi.org/10.1046/j.1467-789x.2001.00037.x

Withrow D, \& Alter DA. (2011). The economic burden of obesity worldwide: a systematic review of the direct costs of obesity. Obes Rev, 12(2), 3110-3141. https://doi.org/10.1111/j.1467-789X.2009.00712.x

World Health Organization [WHO]. (2017). Obesity and Overweight. Geneva: World Health Organization.

World Health Organization [WHO]. (2018a). Metrics: Disability-Adjusted Life Year (DALY). Geneva: World Health Organization.

World Health Organization [WHO]. (2018b). Noncommunicable diseases. Geneva: World Health Organization.

World Obesity Federation [WHO]. (2015). About Obesity. England and Wales: World Obesity Federation.

\section{Copyrights}

Copyright for this article is retained by the author(s), with first publication rights granted to the journal.

This is an open-access article distributed under the terms and conditions of the Creative Commons Attribution license (http://creativecommons.org/licenses/by/4.0/). 